\title{
EFEKTIVITAS PERENDAMAN INDUK IKAN GUPPY (Poecilia reticulata) BUNTING DENGAN BERBAGAI BAHAN, EKSTRAK CABE JAWA (Piper retrofractum Vahl), LARUTAN- 17a METILTESTOSTERON DAN PURWOCENG
}

Vies Mufid Aryoputro, Edward Danakusumah

Fakultas Perikanan dan Ilmu Kelautan Universitas Satya Negara Indonesia

E-mail : vies.aryoputro@gmail.com

\begin{abstract}
ABSTRAK
Penelitian ini bertujuan untuk menguji efektifitas penggunaan ekstrak cabe jawa,-metiltestosteron $17 \alpha$ dan purwoceng dengan teknik perendaman induk guppy bunting terhadap jantanisasi.

Penelitian ini menggunakan Rancangan Acak Lengkap (RAL) dengan perlakuan bahan perendaman induk bunting untuk jantanisasi ikan guppy menggunakan ekstrak cabe-metiltestosteronjawa,dan $17 \alpha$ ekstrak purwoceng yang dibandingkan dengan kontrol (tanpa bahan), masing-masing perlakuan diulangi sebanyak 3 kali ulangan.

Hasil penelitian menunjukkan bahwa bahan yang paling efektif dalam perlakuan perendaman induk ikan guppy terhadap persentase ikan- gupp metiltestosteron dengan hasil tertinggi 90\%, sedangkan untuk bahan alternatif yang ramah lingkungan dapat menggunakan ekstrak purwoceng menghasilkan ikan guppy jantan tertinggi 87\%. Jumlah ikan jantan tersebut lebih tinggi dibandingkan rata -rata ikan guppy kontrol sebesar $77,1 \%$.
\end{abstract}

Kata kunci: Perendaman induk guppy bunting, Piper retrofractum Vahl, 17ametiltestosteron, Pimpinella alpina Molk.

\section{PENDAHULUAN}

Ikan guppy (Poecilia reticulate) adalah salah satu komoditas ikan hias air tawar yang paling diminati pecinta ikan hias diantara keempat ikan lainnya yaitu ikan 
arwana, ikan koi, ikan cupang, dan ikan rainbow (Utami, 2013). Penampilan morfologi ikan guppy jantan lebih menarik dibandingkan dengan ikan guppy betina, yakni memiliki pola warna tubuh yang beragam dan berwarna cemerlang dibandingkan dengan warna tubuh betina yang cenderung monoton (Zairin et al. 2002). Karena itu memproduksi ikan jantan lebih menguntungkan.

Salah satu cara yang dilakukan untuk memenuhi tingginya permintaan terhadap ketersediaan ikan jantan tersebut dengan meningkatkan populasi ikan jantan. Teknik jantanisasi merupakan salah satu metode untuk mengarahkan kelamin ikan menjadi jantan pada masa diferensiasi kelamin. Kelamin tersebut akan berubah menjadi fenotipe fungsional setelah terjadinya proses differensiasi kelamin (Piferrer, 2011).

Penentuan kelamin pada ikan terbentuk pada saat terjadinya pembuahan menjadi zygote saat terjadinya determinasi kelamin dan diferensiasi kelamin yaitu perkembangan kelamin menjadi jantan atau betina secara fungsional. Pada masa diferensiasi kelamin, perkembangan gonad ikan dapat diarahkan dengan mempengaruhi faktor internal atau faktor eksternal (Devlin and Nagahama, 2002).. Peralihan kelamin secara alami disebabkan oleh faktor lingkungan yang tidak mempengaruhi perubahan susunan genetis tetapi hanya merubah ikan betina secara genetik menjadi ikan jantan secara fenotipe atau sebaliknya (Zairin, 2002). Perubahan lingkungan di dalam atau di luar tubuh akan diterima oleh indra disampaikan ke sistem syaraf pusat, setelah itu dikirim ke hypotalamus, kemudian memerintahkan kelenjar hipofisa untuk mengeluarkan hormon gonadotropin yang masuk ke dalam darah dan dibawa kembali ke gonad sebagai petunjuk untuk memulai pembentukan gonad. Perubahan jenis kelamin secara buatan dimungkinkan karena pada saat fase pertumbuhan gonad belum terjadi diferensiasi kelamin dan belum terjadi pembentukan steroid sehingga dapat diarahkan dengan menggunakan hormon steroid (Fujaya, 2002). Teknik jantanisasi untuk mengarahkan kelamin menjadi jantan yang pernah dlakukan diantaranya memanipulasi faktor lingkungan dengan pemberian hormon-MT (Zairin,2002),17 $\alpha$ maupun penggunaan bahan-bahan alami seperti purwoceng (Cahyani, 2014) dan cabe jawa (Winy, 2015). Penelitian ini 
akan menggunakan ketiga bahan alternatif diatas yaitu cabe jawa,-metiltestosteron larutan 1 dan purwoceng dengan dosis terbaik dari penelitian yang telah dilakukan sebelumnya yaitu ekstrak cabe jawa $2 \mathrm{mg} / \mathrm{L}$, larutan- 17 metiltestosteron 5mg/L dan ekstrak purwoceng $10 \mathrm{mg} / \mathrm{L}$.

\section{METODOLOGI}

\section{Waktu dan Tempat Pelaksanaan}

Kegiatan penelitian dilaksanakan selama 56 hari mulai tanggal 15 April sampai dengan tanggal 10 Juni 2018. Yang bertempat di desa Suradita, Kecamatan Cisauk Kabupaten Tangerang.

Penelitian ini menggunakan bahan-bahan yaitu ikan Guppy Jantan sebanyak 48 ekor dengan ukuran 3,5-4 cm, dan ikan guppy betina 24 ekor dengan ukuran $4-5$ cm, cacing sutera, jelly worm, pakan Pelet A-B, air tawar, ekstrak cabemetiltestosteron, dan ekstrak purwoceng. Alat yang digunakan pada penelitian ini yaitu 2 aquarium untuk memisahkan jantan dan betina, 12 wadah volume 5 Liter untuk pemijahan juga untuk pemeliharaan larva, 2 buah aerator dan selang secukupnya, DO meter, pH meter, serokan Ikan, jangka sorong digital, timbangan digital, alat tulis, kamera digital. Ikan guppy yang digunakan dalam penelitian ini adalah induk guppy jantan dan betina yang digunakan berukuran 4-5 cm dengan bobot \pm 3 g. Perkawinan dilakukan dengan perbandingan betina dan jantan 3:2 setiap perlakuan, yang berasal dari pasar ikan hias parung bogor. Padat penebaran dalam kegiatan ini sebanyak 2 ekor /L, pada penelitian ini disetiap wadah rencana akan diisi oleh 5 ekor induk ikan guppy. Wadah pemeliharaan yang digunakan dalam kegiatan ini menggunakan toples berbentuk tabung berbahan polietilene (PE) dengan volume 5 liter dilengkapi aerasi sebagai suplai oksigen.

\section{Pembuatan Larutan Uji}

Semua bahan ditimbang terlebih dahulu sesuai dengan dosis bahan uji yaitu, cabe jawa (2 mg/L), larutan 17 $\alpha$-metiltestosteron $(5 \mathrm{mg} / \mathrm{L})$ dan ekstrak purwoceng (10 $\mathrm{mg} / \mathrm{L})$ kemudian dimasukkan ke dalam gelas piala dan ditambah dengan 4,6 mL alcohol 70\% pada setiap dosis bahan uji. Campuran tersebut diaduk selama 3 jam 
dengan hotplate magnetic stirrer kemudian didiamkan selama 24 jam. Selanjutnya campuran disaring dengan kertas saring (Putra 2011). Ekstrak yang didapatkan diencerkan dengan 1 liter akuades lalu disimpan dalam lemari pendingin $\left(-4^{\circ} \mathrm{C}\right)$ sebagai larutan stok (Dhewantara 2017). Rancangan percobaan menggunakan Rancangan Acak Lengkap dengan (RAL) dalam satu faktor dengan 4 perlakuan masing-masing perlakuan terdapat 3 ulangan. Setiap ulangan perlakuan (satu wadah) terdiri atas 5 ekor calon induk ikan guppy $4-5 \mathrm{~cm}$ dengan bobot $\pm 3 \mathrm{~g}$. Perlakuan dapat dilihat pada Tabel berikut:

Tabel 1. Rancangan Perlakuan Jantanisasi jawa,Ikan Guppy dengan $17 \alpha$ berbagai bahan melalui perendaman induk bunting.

\begin{tabular}{|c|l|}
\hline PERLAKUAN & \multicolumn{1}{|c|}{ KETERANGAN } \\
\hline A & Kontrol negative (tanpa dosis) \\
\hline B & $2 \mathrm{mg} / \mathrm{L}$ ekstrak cabe jawa \\
\hline C & $5 \mathrm{mg} / \mathrm{L}$ larutan $17 \alpha$ - metiltestosteron \\
\hline D & $10 \mathrm{mg} / \mathrm{L}$ purwoceng \\
\hline
\end{tabular}

Model Rancangan Acak Lengkap (RAL) yang akan digunakan adalah sebagai berikut:

$$
\text { Yij }=\mu(\text { Steel }+ \text { tidan Torrie },+ \text { eij1991). Keterangan : }
$$

Yij : Data hasil pengamatan pada perlakuan ke-I dan ulangan ke-j

$\mu \quad$ : Nilai tengah dari pengamatan

ti : Pengaruh aditif dari perlakuan ke-i

eij : Pengaruh galat hasil percobaan

pada perlakuan ke-I dan ulangan ke-j Perlakuan diberikan melalui perendaman induk bunting hingga melahirkan dan dilakukan pemeliharaan larva hingga dapat dibedakan jenis kelamin dengan cara melihatnya secara beda fisik anatomi tubuh. 


\section{Parameter Uji}

Parameter yang diamati meliputi pengukuran persentase jantan betina, pertumbuhan ikan, survival rate dan kualitas air. Prosentase kelamin antara jantan dan betina merupakan parameter utama yang menjadi indikator keberhasilan teknik jantanisasi. Pemberian androgen pada maskulinasi akan menghasilkan hampir $100 \%$ jantan. Demikian juga halnya dengan pemberian estrogen pada proses feminisasi. Jika berhasil, pemberian estrogen pada feminisasi akan menghasilkan hampir $100 \%$ betina. Untuk melihat jenis kelamin jantan dan betina maka dilakukan pengamatan fisik ikan setelah pemeliharaan selama 56 hari.

$$
\% \text { Jantan }=\frac{\text { Jumlah individu jantan }}{\text { Jumlah individu total }} \times 100
$$

Pertambahan panjang Mutlak adalah perubahan panjang rata-rata individu pada setiap perlakuan dari awal penebaran sampai akhir pemeliharaan, dapat dihitung dengan menggunakan rumus dari Effendie (1997):

$$
L=L t-L o
$$

Keterangan :

$\mathrm{L}=$ Pertambahan Panjang Mutlak $\mathrm{Lt}=$ Panjang rata - rata akhir $(\mathrm{mm})$ Lo $=$ Panjang rata -rata awal ( $\mathrm{mm}$

\section{Kelangsungan Hidup}

Menurut Effendie (1997), tingkat kelangsungan hidup merupakan persentase dari jumlah ikan yang hidup pada awal dan akhir pemeliharaan. Rumus dari tingkat kelangsungan adalah sebagai berikut:

$$
\mathbf{S R}=(\mathrm{Nt} / \mathrm{N} 0) \mathbf{x} \mathbf{1 0 0 \%}
$$

Keterangan :

$\mathrm{SR}=$ Pesentase kelangsungan hidup

$\mathrm{Nt}=$ Jumlah larva pada akhir pengumpulan data

No = Jumlah larva pada awal pengumpulan data. 


\section{Kualitas Air}

Pengelolaan kualitas air dilakukan dengan menyediakan filter fisik berupa topfilter. Topfilter diletakkan pada masing-masing akuarium perlakuan. Pengelolaan kualitas air lainnya yaitu dengan penggantian air setiap tujuh hari sekali dengan pengurangan sebanyak $50 \%$ dan diisi kembali dengan air tendon yang juga diberi filter fisik. Pengukuran kualitas air dilakukan sebanyak 8 kali pada hari ke-7, 14, 21, 28, 35, 42, 49, dan hari ke-56. Parameter kualitas air yang diukur adalah suhu, pH, dan DO. Pengukuran suhu dan $\mathrm{pH}$ menggunakan $\mathrm{pH}$ meter, sedangkan DO menggunakan DO meter.

\section{Analisis Data}

Data yang didapatkan diolah menggunakan Microsoft Excel 2016. Parameter presentase kelamin jantan, pertumbuhan panjang dan tingkat kelangsungan hidup, dianalisis ANOVA dengan program SPSS 22.0 pada selang kepercayaan 95\% dan diuji lanjut dengan Tukey apabila berpengaruh nyata. Parameter pertumbuhan ikan dan kualitar air, uji dianalisis secara deskriptif.

\section{HASIL DAN PEMBAHASAN}

\section{Hasil}

Selama penelitian dilakukan pengamatan dan dicatat hasil sebagai data informasi untuk dilanjuksan sebagai bahan analisa pada penelitian, adapun data hasil pengamatan tersebut yaitu persentase jantan, pertumbuhan panjang, tingkat kelangsungan hidup dan kualitas air.

\section{Persentase Jantan}

Pengamatan jenis kelamin dilakukan dengan metode morfologi jantan dan betina berdasarkan visualisasi kelamin sekunder. Perbedaan antara ikan guppy jantan dan betina pada umur 56 hari pemeliharaan sudah nyata. lkan guppy jantan yang sudah dewasa ditandai dengan adanya warna yang lebih terang pada tubuh dan ekor, bentuk ekor menyerupai kipas melebar. Selain itu, sirip punggung lebih panjang serta 
badan terlihat lebih pipih. Sedangkan untuk ikan guppy betina ditandai dengan warna yang gelap pada tubuh dan badan terlihat lebih gendut. Hasil pengamatan pada Kontrol menghasilkan persentase ikan guppy jantan sebesar $77,1 \%$, sedangkan pada dosis ekstrak cabe jawa $2 \mathrm{mg} / \mathrm{L}$ menghasilkan persentase ikan guppy jantan lebih rendah sebesar $67,3 \%$, pada larutan-metiltestosteron $5 \mathrm{mg} / \mathrm{L}$ adalah yang tertinggi menghasilkan 88,6\% ikan guppy jantan dan ekstrak purwoceng 10mg/L menghasilkan 81,2\%. Selengkapnya jumlah ikan jantan dapat disajikan pada Gambar 1 berikut.

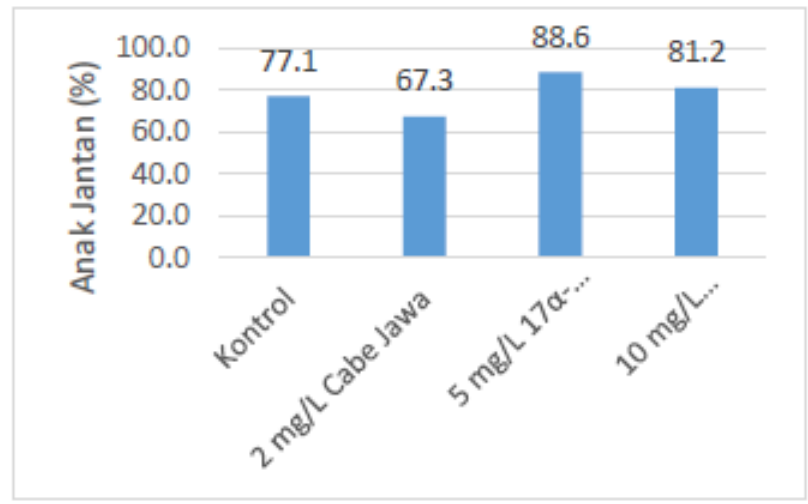

Gambar 1. Perbandingan anak jantan

\section{Pertumbuhan Panjang Mutlak}

Hasil pengukuran terhadap laju pertumbuhan panjang mutlak menunjukkan bahwa nilai laju pertumbuhan rata - rata tertinggi diperoleh pada perlakuan Panjang tubuh ikan uji hasil jantanisasi di sampling pada hari ke 7, 14, 21, 28, 35, 42, 49, dan 56. \%. Selengkapnya laju pertumbuhan panjang anak ikan guppy dapat disajikan pada Gambar 2 berikut. 


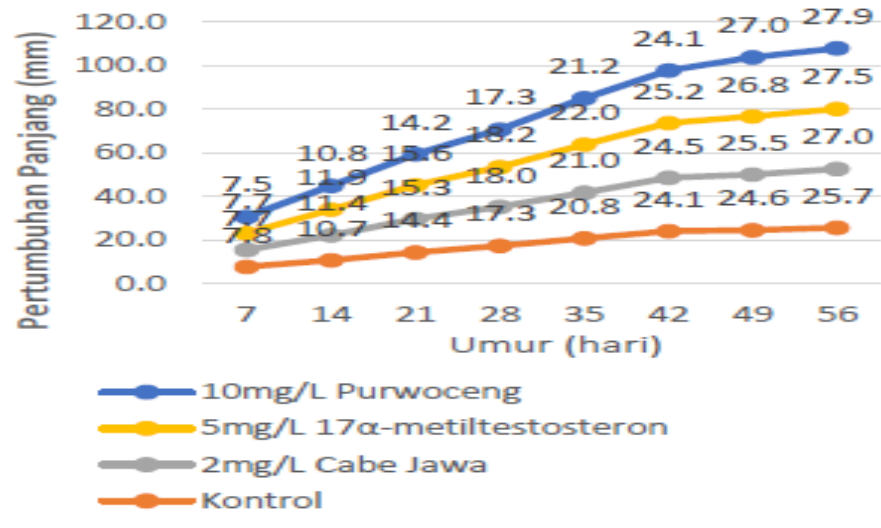

Gambar 2. Pertumbuhan panjang

Panjang rata-rata tubuh anak ikan guppy hasil jantanisasi diukur pada hari ke 7, 14, 21, 28, 35, 42, 49, 56 (Lampiran 3). Rata-rata panjang tubuh yang dicapai oleh ikan uji setelah 56 hari pemeliharaan tertinggi pada anak hasil perendaman induk guppy bunting dengan bahan ekstrak purwoceng yaitu 27,9mm.

\section{Tingkat Kelangsungan Hidup}

Pada perlakuan kontrol hampir tidak ditemukan anak ikan guppy yang mati hingga akhir penelitian atau tingkat kelangsungan hidupnya 98,6\%, sedangkan pada perlakuan perendaman induk bunting dosis larutan cabe jawa tingkat kelangsungan hidupnya 93,2\%, pada induk bunting dengan dosis larutan 17 $\alpha$-metiltestosteron 5mg/L didapati tingkat kelangsungan hidup 92,6\%, sedangkan dalam perendaman induk yang bunting dalam ekstrak purwoceng dosis $10 \mathrm{mg} / \mathrm{L}$ terdapat kematian 12,7\%, Selengkapnya tingkat kelangsungan hidup ikan guppy hingga masa pemeliharaan 56 hari dapat disajikan pada Gambar 3 berikut. 


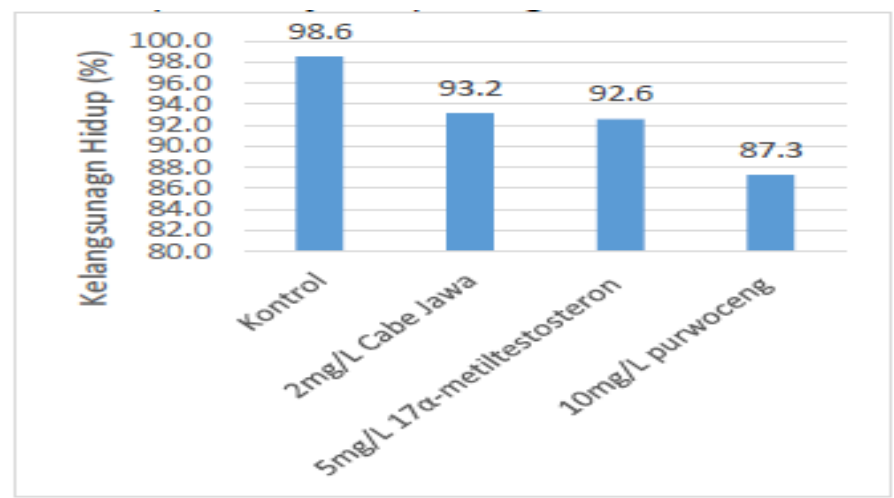

Gambar 3. Kelangsungan Hidup Ikan Guppy

\section{Kualitas Air}

Dari pengukuran suhu saat penelitian diperoleh kisaran suhu dari 27oC 29oC selama 56 hari. Hasil pengamatan selama penelitian $\mathrm{pH}$ air berkisar antara 6,3 6,9. Kandungan oksigen terlarut berkisar antara 5,53-6,45 ppm. Selengkapnya rata rata pengukuran kualitas air ikan guppy hingga masa pemeliharaan 56 hari dapat disajikan pada Gambar 4 berikut.

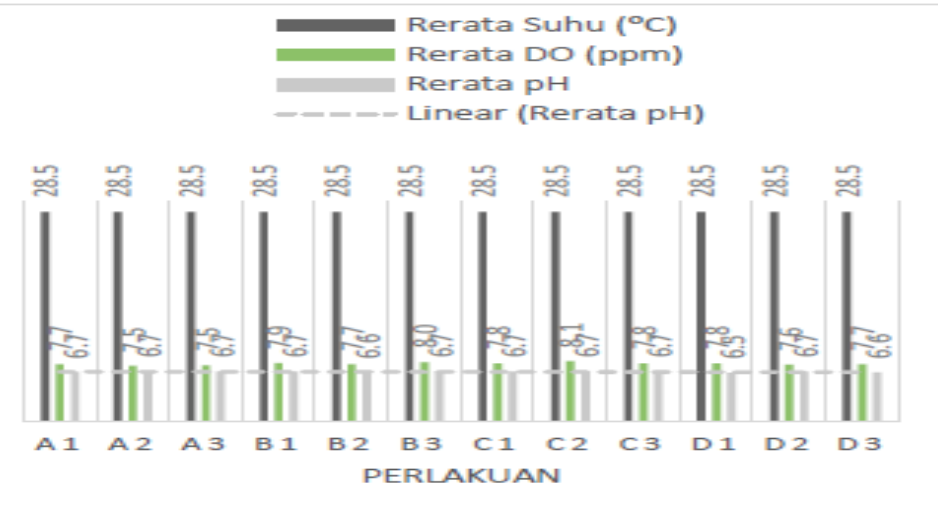

Gambar 4. Uji kualitas air suhu, pH, dan DO

\section{Analisis Data}

Berdasarkan data yang didapat saat penelitian yang terdapat dalam lembar lampiran, bahwa hasil analisis keragaman melalui uji statistik menggunakan aplikasi statistik ibm spss 22 menunjukkan bahwa efektivitas perendaman induk ikan guppy dengan berbagai bahan, ekstrak cabe jawa larutan-metiltestosteron,17 $\alpha$ dan ektrak 
purwoceng memperoleh hasil pada kolom Sig. nilai $\mathrm{P}(\mathrm{P}$-value $)=0,021<0.05$. Dengan demikian efektivitas perendaman induk ikan guppy dengan berbagai bahan, ekstrak cabe jawa larutan-metiltestosteron,17 $\alpha$ dan ektrak purwoceng berpengaruh nyata terhadap jantanisasi. Analisa lanjut dengan menggunakan tukey didapatkan hasil bahwa larutan $5 \mathrm{mg} / \mathrm{L} 17 \alpha$-metiltestosteron terdapat perbedaan yang signifikan pada perendaman induk gappy bunting terhadap jantanisasi.

Hasil analisis keragaman melalui uji statistik menunjukkan bahwa efektivitas perendaman induk ikan guppy dengan berbagai bahan, ekstrak cabe jawa metiltestosteron, dan ektrak purwoceng memperoleh hasil pada kolom Sig. nilai P (Pvalue $)=0,03<0.05$. Dengan demikian efektivitas perendaman induk ikan guppy dengan berbagai bahan, ekstrak cabe jawa larutan-metiltestosteron, $17 \alpha$ dan ektrak purwoceng berpengaruh nyata pada perendaman induk gappy bunting terhadap kelangsungan hidup anak ikan guppy. Analisa lanjut dengan menggunakan tukey didapatkan hasil bahwa perlakuan ektrak purwoceng terdapat perbedaan yang signifikan dengan perlakuan kontrol terhadap kelangsungan hidup anak ikan guppy. Sehingga perlakuan 10mg/L ekstrak purwoceng pada perendaman induk gappy bunting berpengaruh signifikan terhadap kelangsungan hidup anak ikan guppy.

\section{PEMBAHASAN}

Hasil pengamatan pada Kontrol menghasilkan persentase ikan guppy jantan sebesar 74 - 81\%, sedangkan pada dosis ekstrak cabe jawa 2mg/L menghasilkan persentase ikan guppy jantan lebih rendah sebesar 60 - 72\%, lebih tinggi dari perlakuan 2mg/L ekstrak cabe jawa menghasilkan persentase ikan guppy jantan sebesar 56,67\% (Winny, 2015). Pada pengamatan larutan 5mg/Lmetiltestosteron17 $\alpha$ adalah yang tertinggi menghasilkan 85 - 90\% dengan tingkat kelangsungan hidup ikan guppy jantan sebesar $90-95 \%$. Berdasarkan penelitian Yunianti (1995) bahwpera endaman induk yang bunting selama 24 jam dengan dosis metiltestosteron dapat menghasilkan $100 \%$

ikan guppy jantan. Hasil pernelitian Istuanto et al (2015) perendaman indulk bunting dengan $5 \mathrm{mg} / \mathrm{L}$-metiltestosteron $17 \alpha$ didapatkan tingkat kelangsungan hidup 
yang cukup tinggi selama pemeliharaan yaitu $83,79 \%$. Hasil pengamatan selama penelitian bahwa hasil menunjukkan hampir mendekati $100 \%$ dikarenakan bahan uji $17 \alpha$-metiltestosteron adalah bahan yang diproduksi oleh industry lokal, diharapkan menyerupai produk impor ataupun produk paten.

Hasil pengamatan pada 10mg/L ekstrak purwoceng menghasilkan 69 - 87\% ikan larutan $17 \alpha$ guppy jantan, menghasilkan kelahiran yang lebih rendah dibandingkan dengan tanpa perendaman, juga kematian berkisar 6-10\%, sedangkan pada kontrol tingkat kelangsungan hidup anak yang dilahirkan sampai masa pemeliharaan 56 hari sebesar 97 - 100\%. Perendaman induk yang bunting dalam larutan ekstrak purwoceng selama 24 jam menghasilkan nisbah kelamin jantan 60-70 $\%$, lebih rendah dibandingkan dengan tanpa perendaman yaitu sebesar $85 \%$. menghasilkan 74,28 \% ikan jantan dengan kelangsungan hidup yaitu 94,28 \% (Herry, 2015). Diketahui bahwa dosis perlakuan $2 \mathrm{mg} / \mathrm{L}$ ekstrak cabe jawa melalui perendaman induk bunting yang kurang efektif dalam menghasilkan anak ikan guppy jantan yang dilahirkan. Bahkan pada perlakuan tanpa pendaman induk dalam ekstrak purwoceng menghasilkan anak jantan yang lebih tinggi yaitu 85\%. Beberapa faktor yang mempengaruhi hasil penelitian yang telah saya lakukan ini kemungkinan terkait dengan 3 hal, yaitu dosis perlakuan yang tidak efektif, lama pemberian yang kurang efektif, dan metode perlakuan secara perendaman yang kurang efektif. Kualitas air media pemeliharaan diukur sebagai data penunjang, data ini meliputi $\mathrm{pH}$, suhu dan oksigen terlarut (DO). Data kualitas air dapat dilihat pada Lampiran 5. Dari kisaran suhu pada saat penelitian diperoleh kisaran suhu dari $27^{\circ} \mathrm{C}-29^{\circ} \mathrm{C}$. Sesuai dengan pendapat Lesmana (2001) bahwa suhu optimal untuk ikan tropis adalah $27 \mathrm{oC}-29 \mathrm{oC}$, ikan guppy dapat bertahan pada suhu $18^{\circ} \mathrm{C}$ sampai $28^{\circ} \mathrm{C}$ (Elaxamana, 2009). Pada pengukuran $\mathrm{pH}$ saat penelitian 6,3-6,9. Agar dapat hidup dengan baik ikan guppy memerlukan derajat keasaman antara 6,8 sampai 8,0 (Mundayana dan Suyanto, 2004). Jadi pH perairan media pemeliharaan adalah baik karena masih dalam kisaran yang normal. Kandungan oksigen terlarut yang terukur selama penelitian sebesar 5,53 $-6,45$ ppm. Kandungan oksigen terlarut menunjukkan kisaran yang yang menunjang bagi kelangsungan hidup ikan guppy. Menurut Kordi dan Tancung (2007) konsentrasi 
minimum oksigen terlarut dalam air yang dapat diterima oleh seluruh biota air untuk tumbuh dengan baik adalah 5ppm. Sehingga kandungan oksigen terlarut pada penelitian ini sudah lebih baik dari yang dianjurkan oleh referensi. Setelah dilakukan penelitian terhadap anak jantan dan terhadap kelangsungan hidup, maka dilakukan perbandingan antar perlakuan antara rerata persentase anak guppy jantan dan kelangsungan hidup yang disajikan pada Tabel 2 berikut.

\begin{tabular}{|l|c|c|c|}
\hline PERLAKUAN & $\begin{array}{c}\text { RERATA } \\
\text { PERSENTASE } \\
\text { JANTAN (\%) }\end{array}$ & $\begin{array}{c}\text { RERATA } \\
\text { KELANGSUNGAN } \\
\text { HIDUP }(\boldsymbol{\%})\end{array}$ & $\begin{array}{c}\text { TOTAL } \\
\text { JANTAN HIDUP } \\
(\%)\end{array}$ \\
\hline Kontrol & 77.1 & 98.6 & 76.0 \\
\hline $\begin{array}{l}\text { 2mg/l Ekstrak } \\
\text { Cabe Jawa }\end{array}$ & 67.3 & 93.2 & 62.7 \\
\hline 5mg/l MT & 88.6 & 92.6 & 82.1 \\
\hline $\begin{array}{l}\text { 10 mg/l Ekstrak } \\
\text { Purwoceng }\end{array}$ & 81.2 & 87.3 & 70.9 \\
\hline
\end{tabular}

Dari Tabel perbandingan tersebut dapat terlihat perlakuan terbaik adalah $5 \mathrm{mg} / \mathrm{L}$ larutan-metiltestosteron $17 \alpha$ dengan total jantan hidup $82,1 \%$, kemudian kontrol dengan total jantan hidup 76\%, sedangkan pada $2 \mathrm{mg} / \mathrm{L}$ ekstrak Cabe Jawa lebih rendah dibandingkan kontrol yaitu 62,7\%, dan 10mg/L ekstrak purwoceng didapatkan lebih tinggi dari 70,9\% total jantan yang hidup.

\section{Kesimpulan}

\section{KESIMPULAN DAN SARAN}

Setelah melakukan penelitian dapat disimpulkan bahwa perendaman induk bunting dengan ekstrak cabe jawa dosis $2 \mathrm{mg} / \mathrm{L}$ meningkatkan persentase ikan guppy jantan hingga 67,3\%, sedangkan perendaman induk bunting dengan ekstrak purwoceng dosis $20 \mathrm{mg} / \mathrm{L}$ meningkatkan persentase ikan guppy jantan hingga 81,2 $\%$. Bahan yang paling efektif adalah larutan 17 $\alpha$-MT yang menghasilkan 88,6 \% jantan, dibandingkan pada kontrol menghasilkan 77,1 \% ikan jantan. Kemudian pada bahan alternatif yang dapat dijadikan alternative yaitu ekstrak purwoceng.

\section{Saran}


Pengkajian lebih lanjut mengenai penggunaan bahan ekstrak cabe jawa, purwoceng untuk jantanisasi ikan guppy dengan menggunakan metode berbeda, juga pengamatan pada presentase kelamin jantan kelahiran pertama dan kedua dari induk guppy yang telah mengalami perendaman.

\section{DAFTAR PUSTAKA}

Bond C. E. 1979, Biology of Fishes. Saunders College Publishing. Philadelphia. 514 hlm.

Cahyani D. 2014. Maskulinisasi Ikan Cupang Betta splendens dengan Ekstrak Purwoceng Pimpinella alpinamelalui perendaman artemia. [jurnal]. Bogor: Institut Pertanian Bogor.

Contreras-Sanchez WM, Fitzpatrick MS, Schreck CB. 2001. Fate of methyl testosterone in the pond environment: Detection of MT in pond soil from CRSP site. In: Gupta A, McElwee K, Burke D, Burright J, Cummings X, Egna H (eds). Eighteenth Annual Technical Report. PD/A CRSP. Corvallis, Oregon: Oregon.

Devlin, R.H. and Y. Nagahama, 2002. Sex determination and sex differentiation in fish: an overview of genetic, physiological, and environmental influences. Aquaculture 208:191-364.

Darwisito, S. 2002. Stretegi Reproduksi Pada Ikan Kerapu. Makalah Pengantar Falsafah Sains Program Pasca Sarjana. Institut Pertanian Bogor. Bogor.

Darwati, I. dan I. Rostiana. 2006. Status penelitian purwoceng (Pimpinella alpina Molk.) di Indonesia. Buletin Plasma Nutfah 12 (1): 9-15.

Devlin, R. H. and Nagahama, Y. 2002. Sex Determination and Sex Differentiation in Fish: An Overview of Genetic, Physiological, and Environmental Influences. Aquaculture 208: 191-364.

Dhewantara. L. Y. 2017. Maskulinisasi Ikan Guppy Poecilia reticulata Menggunakan Ekstrak Purwoceng Pimpinella alpina [jurnal]. Jakarta: Universitas Satya Negara Indonesia Jakarta.

Effendi MI. 1997. Biologi Perikanan. Yayasan Pustaka Nusantara. Yogyakarta.

Elisdiana Y. 2015. Induksi perkembangan gonad ikan patin siam (Pangasianodon hypopthalmus) jantan dengan pemberian ekstrak cabe jawa (Piper retrofractum) melalui pakan. Bogor: Institut Pertanian Bogor.

Gunawan, D. dan S. Mulyani. 2004. Ilmu Obat Alam (Farmakognosi) Jilid 1. Penebar Swadaya. Jakarta.

Herry D. L. 2015. Hubungan Antara Perendaman Induk Betina Menggunakan Ekstrak Purwoceng (Pimpinella alpina) Dengan Nisbah Kelamin Ikan Guppy (Poecilia 
reticulata). [skripsi]. Bogor: Institut Pertanian Bogor.

Istuanto M, Ferdinand HT, Syaifudin M, Muslim. Jantanisasi Anakan Ikan Guppy (Poecilia reticullata) melalui perendaman Induk Dengan Larutan $17 \alpha$ Metiltesteron. Palembang: Universitas Sriwijaya.

Juniarto A. Z. 2004. Perbedaan pengaruh pemberian ekstrak Eurycoma longifolia dan Pimpinella alpina pada spermatogenesis tikus Spraque dawley [tesis]. Semarang : Universitas Diponegoro.

Lailatushifah, S. (2012). Kepatuhan pasien yang menderita penyakit kronis dalam mengonsumsi obat harian. Dipetik 6 November 2012:

Lesmana, D. A. 2001. Kualitas Air untuk Ikan Hias Air Tawar. Jakarta.Penebar Swadaya.

Piferrer F. 2011. Endocrine control of sex differentiation in fish. Fish Physiology: From Genome to Environment 1: 1490-1499.

Putra S. 2011. Maskulinisasi ikan nila Oreochromis niloticus melalui perendaman dalam ekstrak purwoceng Pimpinella alpina [tesis]. Bogor: Institut Pertanian Bogor.

Moeloek N, Silvia WL, Yurnadi, Bambang W. 2010. Uji klinik ekstrak cabe jawa (Piper retrofractum valm) sebagai fitofarmaka androgenic pada laki-laki hipogonad. Majalah kedokteran Indonesia 60: 254-261

Mukti, A.T., Priambodo, B., Rustidja, dan Widodo, M.S. 2002. Optimalisasi dosis hormone sintesis-metiltestosterin 17 dan lama perendaman larva ikan nila (oreochromis spp) terhadap keberhasilan perubahan jenis kelamin. Universitas brawijaya. Malang.

Mundayana, Y dan R. Suyanto. 2004. Guppy. Jakarta. Penebar Swadaya.

Montgomery, R., Dryer. R. L., Conway, R.W., dan Spector A. A. 1983. Biokimia: Suatu Pendekatan Berorietasi-Kasus Jilid 2 Edisi Keempat. Gajah Mada Univercity. Yogyakarta.

Rahardjo M, Darwati I. 2006. Produksi dan MutuSimplisia Purwoceng berdasarkan lingkungan tumbuh dan tanaman. J. Bahan Alam Indonesia (The Indonesian Journal of Natural Products). PERHIBA5:310-320.

Rahardjo M. 2003. Purwoceng tanaman obat aprodisiak yang langka. Warta Penelitian dan Pengembangan Tanaman Industri 9(2):4-7.

Soelistyowati. D.T., Martati E., Arfah. H. 2007. Efficacy of Honey on Sex Reversal of Guppy (Poecilia reticulata Peters). Bogor: Institut Pertanian Bogor.

Sunandar, dkk. 2006. Perndaman Benih Ikan Gurami Terhadap Keberhasilan pembentukan Kelamin Jantan. Jurusan Perikanan, Universitas Muhammadiyah Malang, Malang. PKMI (1-20): 1-9. 
Susanti,, D. 2003. Pengaruh Pemberian Pakan Yang Berbeda Terhadap Kualitas Air, Kelangsungan Hidup dan Pertumbuhan Ikan Mas (Cyprinus carpio L.) di Keramba Jaring Apung. Bogor: Skripsi. Institut Pertanian Bogor. Bogor.

Susanto, H. 1990. Budidaya Ikan Guppy. Yogyakarta: Kanisius.

Steel, R. G. D. dan J. H. Torrie. 1991. Prinsip dan Prosedur Statistika. Diterjemahkan oleh Bambang Sumantri. PT. Gramedia Pustaka Utama. Jakarta.

Taufiqurrachman and Wibowo. 2005. Effect of purwoceng (Pimpinella alpina) aextract in stimulating testosterone, luteinizing hormone (LH) and follicle stimulating hormone (FSH). in sprague dawley male rats. Prosiding SeminarNasional Tumbuhan Obat Indonesia XXVIII -Bogor.Tancung, A. B., M. Ghufran H Kordi K. 2007.

Pengelolaan Kualitas Air Dalam. Budidaya Perairan. Jakarta: Rineka Cipta

Utami SW. 2013. Peluang ekspor ikan hias. Warta Ekspor Kementrian Perdagangan Republik Indonesia. Jakarta (ID).

Utomo B.2008. Efektivitas Penggunaan Aromatase Inhibitor dan Madu terhadap Nisbah Kelamin Ikan Guppy (Poecillia reticulate Peters). Bogor: Institut Pertanian Bogor.

Wasito H, 2011. Obat tradisional kekayaan Indonesia. Yogyakarta : Graha Ilmu.

Widowati D, Faridah. 2005. Isolasi dan Identifikasi Senyawa Kimia Dalam Fraksi Non-Polar dari Tanaman Purwoceng (Pimpinella alpina). Prosiding seminar nasional tumbuhan obat Indonesia XXVIII. Bogor (ID), 15-16 September 2005.

Winy Y. 2015. Maskulinisasi Ikan Guppy (Poecilia reticulata) Dengan Ekstrak Cabe Jawa (Piper retrofractum Vahl) Melalui Perendaman Induk Bunting. [skripsi]. Bogor: Institut Pertanian Bogor.

Yamazaki F. 1983. Sex control and manipulation in fish. Aquaculture 33: 329354.

Yunianti A. 1995. Pengaruh lama waktu perendaman induk di dalam larutan hormon 17- $\alpha$ methyl testost terhadap nisbah kelamin anakan ikan guppy. [skripsi]. Program Studi Budidaya Perairan, Fakultas Perikanan, Institut Pertanian Bogor.

Zairin M. J, A Yunianti, Dewi RRSPS, Sumantadinata K. 2002. Pengaruh lama waktu perendaman induk di dalam larutan hormon-methyltestosteron $17 \alpha$ terhadap nisbah kelamin anak ikan guppy, Poecilia reticulata Peters. Jurnal Akuakultur Indonesia 1: 31-35.

Zairin M.J 2002. Sex Reversal: Memproduksi Benih Jantan Atau Betina. Jakarta (ID): Penebar Swadaya 